\title{
The Harmony Of Religious People Perspetive Of Christian Group: Intra And Inter-Religious Relations In Ambon
}

\author{
Sitti Arafah ${ }^{1}$, Basman $^{2}$ \\ \{ sittiarafah0702@gmail.com $^{1}, \underline{\text { drbasman@gmail.com }}{ }^{2}$ \} \\ Research \& Development and Training Ministry of Religion Indonesia ${ }^{1}$ Institute of Islamic \\ Religion State Gorontalo ${ }^{2}$
}

\begin{abstract}
This study describes the religious harmony from the perspective of Christian groups in Ambon. This research uses qualitative methods for data collection, including observation, interviews, and documentation processes. The results of this study showed that the conflict between the communities in Ambon had made several changes in the sociocultural life of the people. Muslim and Christian communities are now settling into two separate groups. Meetings between the communities generally only occur in public spaces as well as markets, schools, or offices. The impact of this conflict has affected the relationship between them, it becomes less intimate and more rigid. The conflict also has changed the atmosphere to be more fragile, creates mutual suspicion, and loss of trust among the people. The relationships that have been built internally are well established. However, it's hard to reject that the relations between denominations are not free from the intrigues of frequent conflicts. However, they are still bound in one church fellowship, known as Okumene. Likewise, relations between religious communities are currently being built quite intensively, with their terms "turun menyapa" and "baku dapa" in various meeting occasions as can be seen in the momentum of religious activities such as Idul Fitri and Christmas, as well as other religious activities including MTQ, PESPARAWI, PERPARANI, in addition to other social activities. This study focused on understanding the Christian, perspective about religious harmony between Christian and Islam communities as well as between their respective groups.
\end{abstract}

Keywords: Tolerance, Religion, Perspective, Christian Group, Ambon

\section{INTRODUCTION}

Eliminating conflict and bringing peace in Ambon are still major struggles faced by the community until this day. Efforts that have been made in realizing peace through mediation from the grass-root level and conflict resolution are an effort to strengthen harmony. However, this mediation has not yet fully worked. Harmony is defined as peace or both in view and practice. For the people of Ambon, "harmony" or "community harmony" is a term that is more appropriately used to describe the goals of reconciliation, peace development, and mediation efforts that is still being worked on today. Harmony is a term used to describe the pattern of relationships that society prefers[13]. 
In order to achieve harmony in a society, the main step that must be taken is to overcome ongoing tensions and lack of mutual trust in society. The absence of regular interactions between religious communities creates mistrust and resistance to breed and makes reconciliation more difficult. Besides, there is also a tendency to see every problem from a religious perspective. This thing is a common thing to happen in society, also, some community members are still affected by the trauma of the previous conflict so it is an urgent need to increase government programs to deal with the trauma from the previous conflict. It also needs to be realized that trauma can be experienced by the younger generation, their fear may increasing radicalism in Ambon, emerges new sub-religious groups and cause unrest in the community because of their radical ideology [16].

The roots of suspicion towards others are deeply rooted in several religious groups. Some of these denominational traditions, are characterized by isolationism, confrontation (seeing different religions as rivals to be conquered) and hatred. In fact, every religious adherent has a tendency towards power, so that the boundary between the interests of power and religiosity is very thin.

Today religious harmony in Ambon has generally improved. Communication between religious communities has taken place, even though some parts of the community are still feeling anxious, and as an effort to maintain tolerance and harmony among religious communities, one of the concrete steps taken by the interfaith community is considered as an effort to build friendship between them, known as "turun menyapa" and "baku dapa" in various meeting spaces.

The intern social interaction of the community between religions and the government runs quite well, this is reflected in the attitude of mutual understanding, respect, and mutual trust. If this attitude has been understood and can be implemented in interaction, it will bring an attitude of mutual support and benefit among others. This is what to be developed continuously so that it becomes the basis for creating a peaceful and harmonious atmosphere. Thus, the role of religious groups is very important to maintain religious harmony with various models being used.

This research is important to understanding the internal relation within Christian denominations, especially the existence of the mainstream Christian church, Maluku Protestant Church (GPM) and also known as orang basudara church, and their relation with other Christian denominations such as Pentecostal, charismatic, and including Jehovah Witnesses.

Based on that background, this study will be focused on tolerance from the perspective of Christian groups, which is associated between inter and intra-religious relations. The focus of the problem is: 1) what is the perspective of tolerance for Christian groups in Ambon City. 2) how are the inter and intra-religious relations in Ambon city? The research objectives are: to obtain an

overview of religious harmony and the practice of harmony in Ambon City from Christian religious groups, both inter and intra religious communities.

\section{LITERATURE REVIEW}

\section{Religious Harmony in Regulation}

Religious harmony is an important basis for the strengthening of national harmony. Every religion certainly does not teach enmity instead of religion teaches peace, tolerance, harmony, and harmony [7]. Indonesia is a large nation of various kinds of ethnicities and religions. Thus, relationships between humans, between groups, especially between religious communities have 
the potential to explode and have tension between the various elements [5]. One of the most important issues in Indonesia is the issue of religious harmony. The concept of religious harmony is also known as the "Trilogy of Harmony" which includes intra-religious harmony, inter-religious harmony, and inter-governmental harmony.

Various regulations that have been regulated and made by the Indonesian government as an effort to organize inter and intra relations have been stipulated in the regulations. Article 29 in the 1945 Constitution, specifically in paragraph 2, states that the state guarantees the freedom of every citizen to embrace a religion and belief and believe in that religion and belief. In addition, in the Regulation of Religious Broadcasting based on SKB 2 of the Minister (Minister of Religion and Minister of Home Affairs) Number 1, of 1979 concerning Procedures for Religious Broadcasting, furthermore in PMA No. MA/432 in 1981. These regulations intend to control traffic for each religious adherent to express his religion.

\section{The Paradigm of Religious Harmony}

Apart from the concept of harmony trilogy, there is another paradigm that is considered to have a connection with religious harmony, namely tolerance which means leniency, gentleness, lightness, and patience. In this case, Michael Walzer [18] has divided it into five dimensions: 1) acceptance of differences to live in peace, 2) making uniformity a difference, 3) acceptance that others have rights, 4) express openness to others, want to know, respect, want to listen to and learn from others and 5) full support for differences and emphasize aspects of autonomy. These five dimensions are well explained, first, accepting differences to live in peace means simply accepting differences for the sake of peace after massacring one another. This tolerance model developed in Europe since the 16th century and 17th century AD. Second, he called it a soft concern for differences. In this dimension, the other is recognized as existing but his presence does not mean anything. Third, there is recognition in principle that the other has their rights, even though the expression is not necessarily approved. Fourth, it is not only limited to showing recognition, but also openness to others or at least curiosity to better understand the other, and fifth is no longer just acknowledging and openness to accept others but also supporting, caring for, and celebrating differences. It could be due to the reason that diversity is sunnatullah, it also because of the reason that diversity is the land to nurture human development for the better [14].

Pluralism and multiculturalism are also paradigms that are closely related to harmony. Pluralism does not only mean simply recognition of diversity but also recognition of the political, social, and economic implications of diversity. Multiculturalism is an ideology or understanding that recognizes and expresses differences equally, both individually and culturally [9].

Rob Reich, in understanding multiculturalism divided it into two formulas, known as descriptive multiculturalism and normative multiculturalism. Descriptive multiculturalism is a social reality known to political science experts as a pluralist reality. Descriptive multiculturalism does not recognize the existence of a concept of what is called good. Something that considered good depends on social value. Thus, absolute and single truth is unrecognized in the concept of multiculturalism. The truth is what is considered good by society [9].

Likewise, when referring to Diana L. Eck (2006), true tolerance is not sufficient enough to build a religious life that is truly harmonious and friendly. Tolerance is just generosity to accept the difference. In this situation, there is still a more dominant group. Then Diana L. Eck proposed 
another concept called pluralism. Pluralism is not only limited to tolerance but an attitude full of enthusiasm and active behavior experiencing encounters amid diversity[9].

\section{RESEARCH METHODS}

This research is a qualitative study that aims to describe the relationship between two religious groups, internal relations and between religious communities in Ambon. Data were conducted using three methods. The first is observation, by observing religious groups (Christians) in building internal relations of religious communities. Second, interview was conducted with church leaders from various denominations/ churches led by religious institutions such as FKUB, BAMAG and Christian communities in Ambon. In addition, it also involves expert informants who can provide depth information regarding the relationship between the two groups, both inter and between religious communities. Third, in this research, researchers also seek to present data through documents as the main reference sources and become the primary sources [8].

\section{FINDINGS AND DISCUSSION}

\section{Ambon in Historical Landscape}

Ambon was not only known as the capital of Maluku and North Maluku. When it was not yet divided, long before that, hundreds of years ago, this city had become the headquarters or capital of the Portuguese, Dutch and Spanish colonizers. Based on historical facts and the results of studies conducted by experts, the forerunner of the city of Ambon started from Fort Victoria which was located in front of the independent field which was built in 1775, which was later called the Kota Laha fort or Ferangi which was followed by the presence of community groups who became fortress workers. . These community groups were known as Soa Ema, Soa Silale, Hative, Urimeseng, and Masrdika, followed by Chinese villages and others, where these community groups were the ones who became the crickets for the formation of Ambon city 1775. Historical facts show that the presence of various nations in Maluku also influenced the emergence of various religions. The presence of the Portuguese, Spanish, and Dutch exerted an influence on the spread of Catholicism and Christianity. People of Ambon are known as a society consisting of differences in religion, race, ethnicity, and language. Historical literatures explain that before the arrival of Catholicism in Ambon/Maluku through Portuguese or Protestant influence through Dutch influence, Islam first entered this spice island through the influence of the kingdoms in North Maluku (Ternate, Tidore, Jailolo, and Bacan). The seeds of the Islam-Catholic and IslamProtestant conflicts have existed since the colonialism era due to political and business competition that occurred between Islamic kingdoms in North Maluku (also Hitu on Ambon Island) against the Portuguese and then the Dutch [1].

Colonial intervention in the social life of the Maluku people also strengthened social ties based on Soa territory and the country, in addition to having an impact on social grouping based on religion. The presence of the Portuguese with their Catholicism, and the existence of the Netherlands spreading the Protestant Christian religion was quite wide-reaching areas in Maluku and North Maluku. Although in historical records said that in the past one of the countries/villages, 
Hitumeseng Village, was the center of the spread of Islam for the island of Ambon and its surroundings, the arrival of the Portuguese hampered its spread.

\section{Christianity in Ambon: The emergence of the GPM and the Denomination of Churches}

The situation that always accompanies the presence of churches in Indonesia is diversity, be it ethnicity, culture, linguistic customs, and religion/belief. The fact of diversity (plurality) is believed to be a "gift of God" to be grateful for. And that fact calls for a basic attitude, "pluralism", namely tolerance, respect for different beliefs, and a willingness to dialogue and cooperate. Because of that, the imposition of a belief is a reduction or impoverishment of the wealth of multiple realities. Frankly said, church or Christianity in Indonesia is a form of religion that originates from outside Indonesia just like any major religion in general. If we trace the names of about 800 of these organizations, a small part of the names shows their origins such as Adventists, Bethelites, Baptists, Charismatics, Pentecostals, and Anglicans. This name reflects the origin and the ecclesiastical understanding it embraces. However, some churches are Indonesian products (independently or in partnership), including the Maluku Protestant Church (GPM). But if it is traced carefully, the names they use are literal or somewhat cryptic translations of the names of various organizations and schools of churches located abroad, for example, the Salvation Army and the Assemblies of God Church [2].

John Chr. Ruhulessin, chairman of the Synod of the Maluku Protestant Church (GPM) 20052015, said that Christianity in Maluku will certainly not be exactly the same as Christianity in Europe, even though the Maluku Protestant Church and its affiliated churches in the Netherlands both claim to be a Calvinist church. In line with the statement, Rev. Frans E Serang bluntly said, "Calvin is not the owner of GPM, his teachings are just one of the theological properties that have influenced GPM. Clearly, this sees the church as a mother in a place where believers are educated to reach maturity in the faith. The Maluku Protestant Church prefers the metaphor of orang basudara to understand the church. The choice of this metaphor reduces the impression of the church as an exclusive and all-knowing community so that it understands its vocation as a teacher and educator for people from other religions and cultural communities.

Since its presence in Maluku on February 27, 1905, GPM has been located in the Victorian fort. Protestantism has made history in Maluku society and has become part of the religious elements that enrich Maluku culture through local wisdom. Protestantism is a religion that rests on the church as an institution that serves the people, of course, it has the convenience of formulating change agendas adapted through the context of the society in Maluku.

Apart from GPM as a basudara church, there are also several denominational groups joined the Fellowship of Churches in Indonesia with different sectarian backgrounds. The emergence of a sect in Christianity, especially in Ambon, is normal. The presence of the denomination in Ambon City is a separate story and history. There is also the presence of church denominations outside the mainstream (GPM), such as charismatics, Pentecostals, and other local synods.

Syuhudi. [17], argues, among others: several long historical stories related to the emergence of denominations in Manado, differences in interpreting the Bible, differences in applying religious practices, different methods of preaching the gospel, and the openness of local governments that do not prohibit and limit every denomination that will be present in this area.

In the opportunity to discuss the Interfaith Dialogue activity, Pastor Mayaut, Chairperson of the Ambon Religious Harmony Forum, stated that several causes for the emergence of sects in 
each religion are caused by: 1) differences in understanding and interpretation of religious dogmas and teachings, 2) traditions, 3) organizational patterns and power.

Likewise in Ambon, the presence of various denominations also has its background and history. In Protestantism, many schools don't make Christians different, except for a slightly different perspective. The emergence of a number of schools in Christianity to develop their religion in addition to aiming at educating people to live well together in the kingdom of God. In addition, the emergence of a denomination pioneered by pastors from organizations that have branches in other places, including in Ambon, consists of several members and then establishes an alliance. As the denomination of the Association of the Voice of the Redemption Church (PPKSK) as a separate sect and is part of the Pentecostal section. It was founded by an oil entrepreneur in Maluku in the 50s as an expression of gratitude after recovering from his illness.

It is different from the Isa Al-Masih synod. One of the pastors experienced and felt the bitterness of the conflict that occurred in Ambon at that time. He also explained that the appearance of the synod he currently leads as a branch from Semarang. Initially, he was a congregation from the Elim Tabernacle (Pentecostal) sect, but after the riot he had to go up and down the mountains because of the situation at that time, then he had to say goodbye to the priest in Karang Panjang and moved to Weitu. However, he still provided services, but over time and maybe his prayers are heard by God, then one day he heard that in Semarang there is a church center, called the Synod of Isa Al-Masih. It took quite a long time for him, about 2 to be processed to join the Isa Al-Masih church, and finally, in 2014 the Isa Al-Masih Church was formed in Ambon, which currently provides services to the people, in addition to conducting social activities internally as well as between religious communities.

In principle, the presence of denominations/churches in Ambon is divided into two patterns, namely church attendance as a formation of Indonesian products (alone or in partnership) including the Maluku Protestant Church (GPM). Furthermore, it is due to the readiness of God's servants to expand the denominational network which eventually establishes churches that belong to separate streams, as an effort of a servant of God to provide service to the people.

\section{Dive into the teachings of love in the Bible: Tolerance Perspective of Christian Groups in Ambon}

Man is the image of God (imago Dei) in the Bible. This means that whoever he is regardless of religion and origin should be seen as a brother. The Bible affirms that "God is good to all people" (Ps. 145: 9), and That God raises the sun, even for good and evil people (Matt. 5:45). This signifies that God is the Father 'not only of Christians but the Father of all people. Likewise in (John 17:21) through the Prayer of Jesus "That they may be one like You". Everything taught in the Bible should be reflected in the internal relations of Christians. That's where we get role models and at the same time strength to strengthen harmony between fellow humans regardless of religion, race, ethnicity, and class [19].

Christianity theologically has teachings that come from scripture. Tolerance has become a part of the Christian faith because "Jesus taught us to love our enemies or enemies". As part of faith, the most important thing is its application, where the understanding of faith is what is known is what is applied. If these were both implemented, the attitude of intolerance or crime would not have occurred. In addition, Christians who are based on Jesus will get salvation, but in that way, it is different, every human being is required to follow the principles of the Bible and its laws. Every 
people, both individuals, and groups, have their own beliefs about how to live in this world, with their beliefs, the most important thing is that they respect each other, respect each other, and help each other (abstracted interview).

The path of salvation which originates from the Bible and its laws requires each group to make it happen in the building of a harmonious life, mutual love, mutual respect, and mutual respect as a form of manifestation of religious harmony. The concept of living in tolerance is a part of the Christian faith that must be implemented.

Ambon people are very pluralistic, meeting different groups is inevitable, like it or not, they have to interact with each other and even live side by side. It is very important to animate the values of tolerance to avoid friction and conflict between them, by looking back at how to understand true tolerance. Tolerance is not just appreciating a difference, but tolerance makes a relationship more active in various activities of life together between different groups.

\section{Harmonizing Differences: Inter and Intra-Religious Relations in Ambon}

W.I. Thomas said that social interaction is called the definition of a situation (The definition of The Situation). This concept shows that before someone acts as a response or stimulus that he receives, he will try to give a certain meaning in the situation while he is faced with it. In other words, in a social interaction situation there is an interpretive process which Blumer calls the selfindication process, namely:

The ongoing communication process where the individual knows something, judge, give it meaning, and decide to act on that meaning. This Self Indication process occurs in a social context where individuals try to "anticipate" the actions of others and adjust their actions as they interpret it [17].

The occurrence of conflict between brothers in Ambon has made changes the socio-cultural life, the Islamic and Christian communities now live in separate groups. The encounter between the two is more about meeting in public spaces, such as markets, malls, terminals, schools, and offices, so that the brotherhood between them becomes tenuous and greets each other, reprimanding each other becomes persistent. Conflict makes the atmosphere fragile, creates mutual suspicion, and loses trust between them. Now the life of the people in Ambon is in "their own group", even so, it is still found in several places where people live side by side.

\section{Internal Denomination Relations in Ambon City}

Pluralism in a religious perspective does not only exist in the relationship between religions, but also within the religion itself. Within religion, the plurality is enormous, with the emergence of sects in each religion due to: 1) the existence of understanding and interpretation of religious dogmas and teachings, 2) traditions, 3) organizational patterns, and power, and so on.

In the context of Ambon, the Maluku Protestant Church is the majority church and has strong and historical roots for the Christian communities of Maluku and North Maluku with a total of 754 churches divided into 33 classifications. In Ambon, there are approximately 200 churches divided into 4 classifications and the number of congregations is quite large. Apart from the GPM, there are several denominations whose origins are from outside, for example, advent, baptism, and 
others, or churches that have Indonesian characteristics, even with somewhat literal names such as Salvation Army, Sidang Jema'ah Allah, and the local synod, Isa Al- Masih.

In Christian groups, internal conflicts that often arise as a result of differences in organizational administration in aspects of management or leadership, differences of opinion, baptism, or conquest of the congregation. The struggle for the congregation has become a source of internal conflict, but the principle is that the church is only an organization and saves everything is God and the church is only a tool. Therefore, the church should not only look for congregations in quantity but how to improve the quality of the congregation. Especially in the aspect of faith and morals. The internal relations of the mainstream groups (GPM) and other social groups such as Evangelicals, Pentecostals, Bethelites, and other denominations have joined the ecumenical fellowship except for the Adventist church.

Chairman of the Maluku FKUB, Rev. Ade Manuhutu, said that the relationship between Protestant churches as mainline churches in Maluku and other denominations is very good. So far, there have been no incidents involving the church, even with the Roman Catholic church, there has never been any conflict, except for personal matters.

The points of internal conflict that usually occur in Christian denominations are when the people who change sects, for example, Protestants entering Advent, in addition to other social activities such as free medical treatment where certain churches prohibit their congregations from attending these activities. Another case that was also found was a group of Jehovah's Witnesses who were considered not part of Christianity, so there was no relationship between them. As a result of the absence of a confession, it made it difficult for the Jehovah's Witnesses group to obtain permission to build a church from the Protestants, due to a different understanding internally (interview abstracted).

\section{Inter-Religious Relations in Ambon City}

Apart from looking at the internal relations of religious communities, this research also looks at the interaction between religious groups in the Ambon post-conflict. The segregation is a fact that predates the conflict. After the conflict, social interactions began to fade between the two communities, even in some places physical barricades were created. The absence of regular interactions causes distrust and contention to develop and creates obstacles to reconciliation. Small incidents are still worrying although they can be resolved and do not spread to other groups. Also, that the tendency to see all problems through the perspective of religion is behind the current social problems, as a result of the segregation in Rumah Tiga for example, even the ojek base is divided based on religion [16]. The interactions that have been found to date, although considered limited, as in Arifuddin Ismail's research, they are referred as "formal practices". However, this shows that the tolerance that has begun to manifest in the Ambonese community is now understood as active tolerance through encounters even though it is not yet intense because the living conditions of the Ambon people have been largely separated [7].

Religious events are one of the clear evidence that shows the improvement of tolerance and harmony among religious communities in Ambon City. Various religious activities, both national and international, have been successfully carried out, such as MTQ (Islam), Perparawi (Christian), Pesparani (Catholic), and others. Every religious event between Muslims and Christians supports each other and collaborates, such as the implementation of the National MTQ, Christians become the organizing committee for activities. Apart from that, other Christians have prepared a place 
(home) for caravans coming from various regions, as well as the activities of the Islamic Pesparani and Perparawi to do the same.

The practice of harmony which is still being carried out as an effort of awareness of individuals and groups of the two communities without interference from the government has begun to be intensified, for example building a house of worship, breaking the fast together, celebrating qurban, SIDI activities (circumcision for children Sarane), free medical treatment, assisting social assistance (Islam and Christianity), visits orphanages, which are practiced by several church parties, such as Adventists, Isa Al-Masih, GPM, Pentecostals, Salvation Army, Sidang Jemaah Allah, and others.

Even though the pattern of settlement segregation is still a challenge and if efforts to restore it are carried out by force it will be dangerous. We must not force the integration, we only make initiatives for the younger generation if we can create meeting spaces with various communities to build common spaces as alternative spaces through meeting at any time which they call the "Baku Dapa" room (interview, Abidin Wakano, March 9, 2018 in Ambon).

Settlement segregation has become a collective agreement. However, the practice of harmony can still be found in different community groups such as in the people of Latta Village and Nania Village, the practice of harmony works well in social, economic, and religious relations. Furthermore, in the community in Benteng Atas village, two different communities were also found living side by side, helping each other in social activities, especially on Eid al-Adha, Christians also received sacrificial meat.

\section{Reading Perspectives and Practices of Religious Harmony in Ambon City}

The issue of religious harmony is a broad and complex one. Problems around the establishment of places of worship, defamation of religion and religious broadcasting, as well as news that invites hate speech through social media and the spread of various religious ideas that have come out of the "mainstream" understanding, where there are two extreme poles, namely: 1) characterized by fanaticism, primordialism. And the most dangerous is the group that always says that outside of itself is wrong. 2) The poles of liberalism that value harmony and multiculturalism, but fall into secularism, inclusivism, and pluralism without proper control [10].

The Ambon conflict that has been going on for two years, like other conflicts, has caused other very serious disturbances to the joints of social harmony and the order of harmony between religious communities. The Head of the Ambon City FKUB, Pastor D. Mayaut on the occasion of the dialogue held at the Ambon City Ministry of Religion Office, on March 14, 2018, stated that to form peace and harmony, it is necessary to have the awareness to build tolerance, harmony and internal dialogue, which should not be ignored because of problems or internal relations in one religion, the impact is much bigger than any external problem.

Religion must build a new awareness that pays more attention to humanitarian issues, where the approach to the problem must be inclusive and efforts to create harmonization of religious harmony so that religion must internally have the courage to conduct internal criticism within each other, where the awareness of pluralism is not only in terms of the relationship between religions but especially within religion itself.

The Maluku Protestant Church prefers the metaphor of orang basudara to understand the church. This metaphor choice reduces the impression of the church as an exclusive and allknowing community so that it understands its calling as teachers and educators for people of other 
religions and cultural communities [15]. As a basudara church, the emergence of a sect in Christianity, especially in Ambon, is normal, not a problem, not as something that makes a difference.

It is in line with the statement of the Head of FKUB Maluku Province, Pastor Ade Manuhutu, said that the relationship between Protestant churches as mainline churches in Maluku and other denominations is going very well. So far, there have been no incidents involving the church, even with the Roman Catholic church, there has never been any conflict, except for personal matters.

Internal conflicts that often arise are caused by several factors, including differences in organizational administration in aspects of management or leadership, differences of opinion, baptism, or congregation struggles or church movements and other social activities carried out by certain denominations.

Tensions between churches in the past, especially the Protestant church as the mainstream, with other church groups such as Pentecostals and charismatic groups continued, although not on all fronts. However, as an effort to reduce various issues that could lead to internal conflicts, due to the diversity of denominations, the Indonesian Church Association (PGI) formed an institution, namely ecumenical, as a church fellowship as an extension of the hand in responding to various issues that arise including issues that arise internally. . The Inter-Church Deliberative Council (BAMAG), which was first formed in 1975 in Surabaya (Year of Marthen, 2018) In Ambon City, the presence of BAMAG is important as a forum for churches to conduct deliberations both in religious activities and when issues arise. within the group, the church group may immediately hold a meeting or dialogue.

Furthermore, in the relationship between religious communities, along with the increasing awareness of the community after the conflict, each community makes the condition of religious harmony more real even though it is considered still insistent. Tolerance is not only interpreted at the level of passive tolerance but rather as active tolerance which is expressed through encounters in various social, economic, cultural, and political spaces. Dialogue is not only carried out verbally but is more about tolerance for real actions that touch more on the human realm, for example discussing environmental, health, poverty, and so on, although some think that these encounters are still formal and rigid. Social interaction reinforces mutual acceptance, love, mutual respect, and mutual respect.

This is certainly in line with what Walzer [18] said as active tolerance, even though the condition that remains from the post-conflict conflict occurs, which is better known as residential segregation. Efforts to restore their living conditions to what they were before the conflict were still considered very difficult. This is because some people feel at home and comfortable with the current conditions, and most have sold their houses or lands or exchanged properties when they return to their original place of residence, it means they will start from scratch.

\section{CONCLUSION}

Tolerance is a building of religious harmony in Ambon from the perspective of Christian groups, becoming part of the Christian faith to become the teaching of love for others. Despite the fact that in Christian groups divisions and conflicts are considered real problems and cannot be

avoided. Truth claim is still often the main conflict for charismatic Christian groups who are more 
radical and extreme in terms of dogma such as baptism and several other prohibitions. And in particular, the Jehovah's Witness sect which is considered to be not part of Christianity and vice versa for the Jehovah's Witnesses saying that Jesus is another Jehovah is not true.

The internal relations of Christian groups are carried out in various social and religious activities, as well as the existence of several religious institutions or church organizations both national and local such as the Ecumenical institution, BAMAG, LAIM, as a forum for sharing and resolving any problems that arise between the intern and between religious people. Likewise, the relations between religious communities that are currently created for Christian groups have been awakened from the awareness of society that no longer wants to live in a past downturn.

The practice of tolerance and relationships that are currently created in Ambon society is no longer interpreted as passive tolerance. The relationships that are currently created, even though they are still considered formal and tough by looking at the practices in meeting spaces with the term "baku dapa" and "saling sapa", the social interaction of society have entered into an active tolerant dimension that no longer talks about theological aspects, but how to knit tolerance and harmony in the sense of humanity as an effort to revive individual or group awareness as basudara.

Acknowledgements. Authors would like to thanks all informants in this study, especially the leaders of the church denominations in Ambon, who cannot be named one by one, officials of Ministry of Religion of Ambon, and to other informants who have provided data and information for this study.

\section{REFERENCE}

[1] Al Qurtuby. Sumanto. 2018, Islam dan Kristen Dinamika Pascakonflik dan Masa Depan Perdamaian di Ambon. $1^{\text {st }}$ Ed; Yogyakarta: Gunung Mulia.

[2] Aritonang. Jan S, 2016. Berbagai Aliran Di Dalam dan Di Sekitar Gereja, Jakarta: Gunung Mulia.

[3] Arikunto. Suharsini. 2002, Prosedur Penelitian: Suatu Pendekatan Praktik, Jakarta: Rineka Cipta.

[4] Dokumen Keesaan Gereja Persekutuan Gereja-Gereja di Indonesia (DKG-PGI) 2014-2019, 2016: PT. BPK Gunung Mulia: Jakarta.

[5] Hidayatullah and Ahmad, (Ed), 2016. Relasi Antar Umat Beragama di Berbagaia Daerah, Jakarta: Puslitbang Kehidupan Keagamaan.

[6] Ismail, Arifuddin. 2017. Prahara Yang Terselubung, $1^{\text {st }}$ Ed; Yogyakarta: Trussmedia Grafika.

[7] Ismail. Faisal. 2017. Islam Yang Produktif Titik Temu Visi Keumatan dan Kebangsaan, $1^{\text {st }}$ Ed; Yogyakarta: IRCi.Sod.

[8] Kasniyah. Naniek, 2012, Tahapan Mementukan Informan dalam Penelitian Kualitatif, Yogyakarta: Ombak.

[9] Mastiyah. Iyoh, 2018. Pesantren, Iptek dan Multikulturalisme Membaca Fenomena Ribuan Santri Berprestasi dan Moderat, Jakarta: Pesagimandiri Perkasa. 
[10] Mayaut, 2018, in an Article delivered to Dialog Lintas Agama, Ministry of Religion Office, Ambon.

[11] Nuhuyanan, M. Zein. 2010. Konflik dan Integrasi Sosial (Kajian Terhadap Integrasi Etnis Antara Pendatang dan Pribumi di Kota Ambon), Research Report: Institut Agama Islam Ambon.

[12] Pariela. D. Tonny, 2008. Damai di Tengah Konflik Maluku Preserved Capital sebagi Basis Survival Strategy. Salatuga: Universitas Kristen Satya wacana.

[13] Silalahi, Ester,. 2016. Panduan Mediasi untuk Praktisi Perdamaian diAmbon, Center for Humanitarian Dialogue, The Habibie Center and Institut Tifa Damai Maluku.

[14] Syamsurijal, 2018. Kerukunan Umat Beragama Dalam Perspektif Berbagai Kelompok Agama di Kawasan Timur Indonesia, in Operational design, Makassar: Balai Penelitian dan Pengembangan Agama Makassar.

[15] Rahabeat, Rodulf dan Simina, Johan. 2017, Menuju Gereja Orang Basudara Refleksi 500 Tahun Protestanisme dari Maluku, Salatiga: Satya Wacana University Press.

[16] Rasyid, Imron. 2016. Peta Jalan Menuju Rekonsiliasi Ambon, Center for Humanitarian Dialogue, The Habibie Center and Institut Tifa Damai Maluku.

[17] Syuhudi. Muhammad Irfan. 2018, Pergulatan Kepentingan Politik Dalam Relasi Inter Denominasi Kristen di Manado, dalam Jurnal Alqalam, Volume. 24, No. 2, December 2018.

[18] Walzer, Michel. 1997. On Toleratio; New Haven and London: Yale University Press.

[19] Yewangoe, A.A. 2016. Agama dan Kerukunan, Cetakan, ketujuh; Jakarta: Gunung Mulia. 